\title{
BANKA İŞGÖRENLERİNİN SOSYAL SERMAYE VE İŞ TATMİNİNE İLISSTİN ALGI DÜZEYLERİNIN BELİRLENMESİNE YÖNELİK BİR ARAŞTIRMA ${ }^{1}$
}

\section{A RESEARCH ON DETERMINING THE SEVERAL LEVELS OF SOCIAL CAPITAL AND BUSINESS IN BANK HOLDERS}

\author{
Öğr. Gör. Dr. Emel ABA ŞENBAYRAM² \\ Dr. Öğr. Üyesi Cuma ERCAN³
}

\begin{abstract}
Öz
Günümüzde ekonomik, siyasi, kültürel ve sosyal alanda bir bütünleşmenin yaşandığı aşikârdır. Özellikle teknolojik ve iletişim alanındaki gelişmeler, fiziki ve insan sermayesi yetersiz bırakmakta, bunun sosyal sermaye ile güçlendirilmesi gerekliliğini ön plana çlkarmaktadır. Bu durum iş hayatında "neye sahip olduğun veya neyi bildiğin değil kimi tanıdığın önemlidir" sözünün haklılığını kanıtlar niteliktedir. Çalışmada, işgörenlerin sosyal sermaye birikimlerinin iş tatmin düzeylerine etkisinin araştırılması amaçlanmıştır. Bu amaçla, Şanlıurfa, Gaziantep ve Diyarbakır'da faaliyet gösteren toplam 310 banka yetkilisi ile yapılan araştırmada, banka işgörenlerinin sosyal sermaye algı düzeyinin yüksek olduğu tespit edilmiştir. Ayrıca sosyal sermayenin işgörenlerde iş tatmini sağladığı ve bireysel ve örgütsel performansa artı değer kazandırdığı tespit edilmiştir.
\end{abstract}

Anahtar Kelimeler: İşgören, Sosyal Sermaye Birikimi, İş Tatmini Düzeyi

JEL Sinıflandırması: G 20, G41.

\section{Abstract}

Today, it is obvious that an integration in economic, political, cultural and social context is experienced. In particular, developments in technological and communication fields leave physical and human capital inadequate, and it is necessary to strengthen this with social capital. This is evident in business life, "it is important that you know what you have or what you do not know." In the study, it was aimed to investigate the effect of occupations on job satisfaction levels of social capital accumulation. For this purpose, it was determined that the level of perception of social capital of bank employees was high in the survey conducted with 310 bank officials in Şanliurfa, Gaziantep and Diyarbakır. It has also been found that social capital provides job satisfaction in occupations and adds value to individual and organizational performance

Keywords: Occupation, Social Capital Accumulation, Job Satisfaction Level.

JEL Classification: G 20, G41.

\footnotetext{
${ }^{1} \mathrm{Bu}$ çalışma Kilis 7 Aralık Üniversitesi SBE İşletme ABD’de, Emel ABA ŞENBAYRAM tarafından hazırlanan "Bankaların, Sosyal Sermayesi Güçlü İşgören Kayıplarına Karşı Tutumu: “GAP Bölgesi Örneği” konulu doktora tezinden yararlanılarak hazırlanmıștır.

${ }^{2}$ Harran Üniversitesi Suruç Meslek Yüksek Okulu, emel.aba@harran.edu.tr

${ }^{3}$ Kilis 7 Arlık Üniversitesi, İ.İ.B.F., cercan@kilis.edu.tr
} 


\section{GíRiş}

Ekonomik gelişmelerdeki dinamiklik ve esneklik, yıpratıcı rekabet koşulları, yaşamın birçok alanında var olan alternatifler (mal, marka, iş, işgören, örgüt vb.), eğitim, bilişim ve teknolojik olanaklar, bireyleri, örgütleri hatta ülkeleri daha yoğun bir uğraş içerisine sokmaktadır. Böyle bir durumda, rekabet ortamında artı değer yaratacak her türlü unsur önem teşkil etmektedir. Ekonominin dinamik yapısı zaman içerisinde " ne üretirsem onu satarım" anlayışı yerini "neyi nasıl üretirsem satabilirim" anlayıșına bırakmıştır. Hizmet sektörü başta olmak üzere piyasadaki müşteri memnuniyeti algısı da alternatiflerin türemesi ile değişikliğe uğramıștır. Diğer bir deyişle mevcut rekabet koşulları müşteri sayısının yüksekliğinden ziyade müşteri sadakatinin ön plana çıkmasına neden olmaktadır. Dolayısıyla bu durumda güven temelli oluşturulan ilişkilerin finansal getiri sağlayabilecek ortamların yaratılması ve bunun sürdürülebilirliğinin sağlanması da oldukça önemlidir.

Kişi, kurum ve ülkelerarası güvene dayalı ilişkilerin ekonomik bir yansıması olan sosyal sermaye, günümüzde örgütlerin gelişmişlik düzeylerini sadece ekonomik sebeplere bağlı olmadığının göstergesidir. Örgütlerin ekonomik alandaki başarısı sadece sahip olduğu finansal varlık, yetenekler veya sosyal ağlara bağlı değil aynı zamanda çalışanlarının da beşeri ve sosyal yeteneğine bağlıdır. Bireyler çalışanı oldukları örgütlere performansları ile katkı sağlarken varlıkları ile de olumlu yönde etkileyebilmektedirler. Özellikle beșeri sermayelerinin yanında sağlıklı iletişim ağlarına sahip olan ve bu ağları değere dönüştürebilme kabiliyetine sahip olan işgörenler, bireysel ve örgütsel getiriyi arttıracaktır. Aynı koşullar altında yer alan işgörenler arasında sosyal sermayesi yüksek olan ve bunu işyerinin lehine kullanabilen işgörenler kuşkusuz tercih edilenler arasında yer alacaklardır. Dolayısıyla söz konusu işgörenlerin iş yerinden memnuniyetleri ve bağlılıkları da oldukça önemlidir. Günümüzde beşeri sermayelerinin yanında güçlü sosyal sermaye birikimine sahip olan işgörenlerin, tercih edilen değil tercih eden konumunda bulunduklarını da söyleyebiliriz. Bu durum, başta temel taşını güvenin oluşturduğu bankacılık sektörü olmak üzere tüm sektörler için geçerliliğini korumaktadır.

\section{GENEL ÇERÇEVEDE SOSYAL SERMAYE}

Küreselleşmenin de etkisi ile son yıllarda başta ekonomi olmak üzere dünyada birçok platformda hızlı bir değişim ve gelişim süreci başlamıştır. Söz konusu sürece ayak uydurabilme çabası, doğrudan ve dolaylı olarak tüm kişi, kurum ve ülkeleri kapsamı alanına çekmektedir. İletişim ve bilgi teknolojisinde gelinen son nokta, dünyanın küçük ve tek bir pazara dönüștüğünün kanıtı niteliğindedir. Dolayısıyla bu durum iş hayatında "neyi bildiğin değil, kimi tanıdığın önemli" sözünün neden sıkça kullanıldığını açıklamaktadır. Günümüzde çalışanlar arası diyalog ve ortak paydada buluşabilme imkân ve gayretleri, kurumların performans değerlemesi açısından bu dinamikleri göz ardı etmelerinin mümkün olmadığını göstermektedir. Bu noktadan hareketle "güvene dayalı karşılıklı ilişkiler" şeklinde açıklanabilecek olan sosyal sermayenin çalışma hayatındaki ehemmiyeti netleşmektedir.

İktisadi bir geçmişe sahip olan sermaye kavramı hala bazı az gelişmiş ülkelerde ekonomik anlamda her şeyin tek sebebi ve sonucu olarak görülmektedir. Sermayenin sadece para ve paranın satın alabildiği her türlü kıymetli varlık olarak algılandığı toplumlarda refah düzeyi tam olarak sağlanamaması, eşit temel koşullara sahip gelişmiş 
ve az gelişmiş toplumlar arasındaki farkı ortaya koyan unsurlardan en önemlisi sayılmaktadır. Toplumun, bilim çevrelerinin ve kamu otoritelerinin çalışma alanında yoğun bir şekilde işgal eden sermaye kavramı çağın getirdiği yenilik ve ihtiyaçlara göre yeniden ele alınmış ve şekillenmiştir.

Toplumların ekonomik ve siyasal alandaki faaliyetlerinin sosyal çevre olgusu zemininde şekillendiren sosyal sermayenin, kavramsal olarak tek bir ifadesinin yapılması mümkün değildir. Geniş bir çalışma alanına sahip olan bu kavram yıllar boyunca birçok çalışmada farklı açılardan tekrar tekrar tanımlanmaya ve ölçülmeye çalışılmıştır. Bu durum sosyal sermaye kavramın tanımlanmasında belirsizliğe yol açarken zengin bir altyapıya kavuşmasını sağlamıştır. Sosyal sermaye kavramının ilgi çekici olmasının, farklı disiplinlerin ortak noktası olmasından mı yoksa kavramın çok yönlü bir anlatım zemininde olmasından mı kaynaklanır bilinmez ama net bir tanımlamaya sahip olmamasının temelinde farklı bakış açılarının yattığı kesindir.

Çerçevede tanımlayacak olursak sosyal sermaye; en az iki taraf arasında kurulabilen güvene dayalı, yatay (aynı toplum kesimleri arası) ve dikey (yönetenle yönetilen, farklı toplum kesimleri arası) karakterli ilişkilerin yoğunluğudur.(Karagül,2012:93) Yani sosyal sermaye; ilgili toplumdaki ekonomik, sosyal ve siyasal alandaki başarı ve istikrarla yakından ilişkilidir. Bu nedenle insana ve sosyal değerlerin gelişimine yatırım yapmak, küresel rekabette başarılı olmayı kolaylaştırmaktadır.(Karagül ve Dündar, 2006:64) Dünya Bankası ise sosyal sermayeyi şu şekilde açıklamaktadır(Word Bank, 1998:1);

Bir toplumun sosyal sermayesi, insanlar arasındaki etkileşimi yöneten ve ekonomik ve sosyal kalkınmaya yardımcı olan kurumları, ilişkileri, davranışları ve değerleri içermektedir. Bununla birlikte sosyal sermaye, sadece toplumu destekleyen kurumların bir toplamı değil; aynı zamanda onları bir arada tutan bir yapıştırıcıdır. Kişisel ilişkiler, güven ve toplumu "bireylerin topluluğu" olarak tanımlayan ortak bir "yurttaşlık" hissi olarak ifade edilen sosyal davranış için paylaşılan tüm değerler ve kuralları içermektedir.

Fiziki, finansal ve beșeri sermaye kavramları baştan itibaren iktisat disiplini içinde ortaya çıkmış ve geliştirilmiş oldukları halde, sosyal sermaye onlardan farklı olarak iktisattan, sosyoloji, işletme, siyaset bilimi ve sağlık bilimlerine kadar değişen pek çok disiplinde eş zamanlı olarak geliştirilmektedir. Ekonomik, sosyal ve siyasi alanları birleştiren ve bu nedenle de farklı analiz düzeylerinde ele alınması gereken sosyal sermaye kavramının, tanımlanması ve ölçülmesi halen sorunludur. Başta iktisat ve sosyoloji olmak üzere siyaset bilimleri, eğitim sosyolojisi, organizasyon bilimleri gibi farklı disiplinler, kendi kuram ve yöntemleri ile kavramı tanımlama ve ölçme çabalarını oldukça zenginleştirmişlerdir. Bu yöndeki çabaların aynı zamanda disiplinler arası sınırların aşılmasına yaptı̆̆ katkı ise belki de işin en ilgi çekici ve önemli tarafidır(Eselcan, 2009:248).

Sosyal sermayenin unsurları, sosyal sermayenin oluşturulmasını ve geliştirilmesini sağlayan ve birbirleriyle etkileşim içerisinde olan kaynaklar ve aynı zamanda sosyal sermayenin de birer sonucu olabilen olgulardır(Ögüt ve Erbil, 2009:15). Putnam (1993) sosyal sermayeyi, "sosyal kurumun koordine edilmiş eylemlerini kolaylaştırarak toplumun etkinliğini arttıran güven, normlar ve sosyal ağlar gibi 
özelliklerdir" şeklinde tanımlarken unsurların her birinin (güven, norm ve ağlar) kavramı şekillendirirken ve başlı başına birer olgu olduğu da belirtilmelidir. Sosyal sermayenin ölçümü ve analizi hususunda sıklıkla kullanılan unsurların, toplumun ahlak ve düzeni konusunda önemli birer faktör oluşu, her birinin ayrıntılı bir şekilde incelenmesi gerekliliğini doğurmaktadır.

Güven; Sosyal sermayenin öncü isimlerinden Putnam ve Coleman güvenin sosyal sermayenin anahtar ögesi olduğu konusunda fikir bilirliği sağlarken, Bourdieu çalışmalarında güvenden dolaylı olarak bahsetmektedir. Fukuyama ise güveni sosyal sermayenin ana ögesi olarak tanımlayarak sosyal sermayeyi bir toplumda güvenin hüküm sürmesiyle oluşan kapasite olarak tanımlamıştır(Field,2008:88). Sosyal sermayenin oluşması ve sürdürülebilirliği hususunda önemli rol oynayan güven olgusunun ekonomik başarı ve demokrasinin gerekli koşulu olması yönündeki fikir birliği oldukça kuvvetlidir. Toplumsal güven düzeyinin yüksek olduğu ülkelerde başarılı büyük şirketlerin varlığı tesadüf değildir. Dolayısıyla bireysel ve toplumsal güven düzeyinin başarı ve istikrarla paralel olduğunu aşikârdır.

Normlar; Bireylerin eylemler karşısındaki düşünce ve davranış biçimlerini belirleyen, toplumsal açıdan değerlendirildiğinde bağlayıcı olma özelliği olan, işlevlerine, içeriklerine ve uygulanma türlerine göre birbirinden farklılık gösteren, zaman ve gelişmelere göre değişiklik gösterebilen yazılı ve yazılı olmayan kurallar bütünüdür. Bireylerin davranışlarını sınırlayıcı etkisi olması sebebiyle normlar benimsendikten ve çoğu üyelerce kabul edildikten sonra dinamik bir baskı aracına dönüşebilmeleri muhtemeldir. Bireyler toplum tarafından benimsenmeyen davranışlardan kişisel amaçlara ters düşmesine rağmen uzak durabilirler. Bu nedenle normlar bazı durumlarda sosyal baskı niteliği taşıyabilmektedir (Eren, 2006: 116). Bireylerin toplumsal düzeni bozmadan, hedeflerini gerçekleştirebilmelerini kolaylaştıran normlar, sosyal sermayenin kalitesi ve istikrarı açısından oldukça önemlidir. Toplumsal düzenin somut hali diyebileceğimiz bu kurallar bütünü her bireysel çıkarların göz ardı edilerek toplumsal çıkarların ön plana alındığı bir yapıdır. Dolayısıyla bu şekildeki bir anlatım ile normların her şartta sosyal sermaye açısından olumlu sonuçlar çıkarılacağını söylemek doğru olmayacaktır.

Sosyal Ağlar; Sosyal bir varlık olan insanın, diğer kişi ve gruplarla iletişim halinde olması doğası gereği var olan bir durum olmakla birlikte, yatay ve dikey eksendeki iletişimi hayat kalitesi için oldukça önemlidir. Gerekli ihtiyaçların giderilmesi veya bir takım amaçların gerçekleştirilmesi için gerekli olan iletişim ağları fiziksel, yasal, örfi veya davranış şeklinde olabilmektedir. Dolayısıyla özneleri birbirlerine yaklaştıran iletişim ağlarının bütününü oluşturan ağlar, sosyal sermayeyi var eden temel bileșenlerden bir diğeridir. Sosyal sermaye ile ilgili yapılmış olan çalışmaların odak noktasında ağların, sosyal sermayeyi tasarlayan bir unsur olduğu düşüncesi yatmaktadır. Sosyal sermayenin ana fikri, sosyal iletişim ağlarının değerli bir servet olduğudur. İletișim ağları, sosyal bağlılık için bir temel oluşturur; çünkü sosyal bağlılık, karşılıklı avantajlar için- yalnız insanların doğrudan tanıdıklarıyla değil- bir kişinin diğeriyle ortaklaşa çalışmasını sağlar (Field,2008:16).

Woolcock (1998)'a göre diğer tüm koşullar sabit iken, yüksek sosyal sermaye sahip toplumların daha güvenli, daha temiz, daha sağlıklı, daha kültürlü, daha iyi yönetilen ve genelde daha az sosyal sermayeye sahip olanlara klyasla daha mutlu olduklarını ileri sürmektedir. Çünkü ona göre, sosyal sermayesi yüksek olan toplumların 
üyeleri iyi işler bulabilir ve bu işi muhafaza edebilir, kamusal yarara dönük projelere aracı olabilir, sözleşmeli düzenlemeleri uygulamaya geçirebilir, mevcut kaynakları daha etkin kullanabilir, çözüme yönelik önerileri daha barışçll bir biçimde yorumlayabilir ve böylece sorunlara daha uygun çözümler üretebilirler (Michael,1998:155).

\section{IS HAYATINDA SOSYAL SERMAYE}

Ekonomik sermayenin elde edilmesi, arttırlması ve muhafaza edilebilmesi süreci, beșeri sermayenin sosyal sermaye ile pazarlanabilmesi süreci ile paralellik göstermektedir. Diğer bir deyişle akademik hayatın iş hayatına geçişi ile sahip olunan beșeri sermayenin, etkin ve verimliliği için sosyal sermaye aracılığı ile reklam ve pazarlığının yapılması gerekmektedir. Beşeri ve hatta entelektüel sermaye için katalizör görevi üstlenen sosyal sermaye, sosyal ağlar ve karşıllklllık ilkesi dâhilinde bireylerin mevcut koşullarda istenilen hedeflere ulaşılmasını hızlandırmaktadır. Bu noktada belli bir doyuma ulaşan birey, karşılıklı güven, iyi niyet, işbirliği, dayanışma gibi birçok topluma fayda sağlamaya yönelik fikirlerle hareket edecektir. Böylece sosyal sermaye sayesinde toplumda sinerji ve iş birliği oluşmuş oluşacak, çok yönlü ve birbirini destekleyecek faaliyetlerin arttığı görülecektir.

Bireyin iş arama sürecinin mümkün oldukça daha kısa ve daha az tahrip edici olmasını sağlayan sosyal sermaye, işi iyileștirme sürecinde de oldukça etkilidir. İşgücü piyasası ile ilgili yapılan çalışmalarda iş arayanların çoğunun arkadaşları ve aileleri vasıtasıyla iş buldukları belirtilmiştir (Montgomery, 1991: 1408). Sosyal sermaye ve kariyer arasındaki iliş̧inin incelendiği birçok çalışmada ise sosyal sermayenin bireyleri sistem içerisinde meşrulaştırırken elde edilen sosyal sermaye birikimi ile kariyer planlamasında etkin rol oynadığı yönündeki görüşünü desteklemektedir. Seibert ve arkadaşları, sosyal sermaye ve kariyer başarısı arasındaki ilişki ile ilgili yaptıkları araştırmada, sosyal sermayenin, örgüt içinde bireyin daha fazla bilgiye zamanında erişme, daha çok finansal ve maddi kaynağa erişme ve sosyal sistem içinde daha görünür, meşru hale gelmeyi sağlayarak kariyer başarısını etkilediği belirtilmiştir. Çalışmada kariyer başarısı, mevcut ücret, bütün kariyer boyunca ilerlemeler ve kariyer tatmini olarak ele alınmıștır (Seibert, Maria, Robert, 2001: 219-225).

Önceleri örgütlerin odak noktası müşteri sayısının fazla oluşu iken şimdilerde önemli olan sadık müşterilerin devamlılığını sağlamaktır. Artan rekabet ve alternatifler örgütleri bu yönde strateji geliştirmeye itmiştir. Aynı durumun işgücü piyasası için de geçerli olduğunu söylemek gerekmektedir. Örgütler birçok açıdan güçlendirilmiş işgörenleri tercih etmekte ve iş yerine bağlılıklarını arttırmayı hedeflemektedirler. Özellikle hizmet sektöründe faaliyet gösteren örgütlerde sosyal ve beșeri sermaye birikimine sahip işgörenlerin iş yerinde devamlılığını sağlamak oldukça önemlidir. Sosyal sermaye birikimi güven esasına dayalı ilişkilerden oluşması sebebiyle müşteriçalışan iliş̧kisinin muhafaza edilebilmesi ve söz konusu bu bağın sürekliliğini sağlamak örgüt için hayati öneme sahiptir.

\section{1. İş Tatmin Düzeyi ve Sosyal Sermaye İlişkisi}

Sosyal sermaye bireyleri, kazandıkları güven, dürüstlük, adalet, dayanışma, fedakârlık gibi sosyal erdemleri toplumsal çıkarlar doğrultusunda kullanmaya ve teşvik ettirmeye yarayan bir mekanizmadır. Bu mekanizmayı harekete geçiren en önemli faktör ise güven duygusudur. Bu doğrultuda bahsedilen, bireylerin birbirlerine, topluma, idari ve siyasi otoriteye olan döngüsel güven hareketidir. Güven duygusu çalışanların iş tatmin 
düzeylerini, motivasyonlarını, aidiyet duygularını arttırırken, örgütlerin de performansları üzerinde etkili olan doğal bir güçtür. Bu durum da, karşılıklı güven esasına dayalı sosyal sermayenin, işyeri verimliliğini ve işgören performansını doğrudan etkilediği söylenebilmektedir. Hodson (1997) çalışmasında güvenin ve sosyal desteğin yanında grup dayanışması da sosyal sermaye ve iş tatmini arasındaki ilişkiyi kuvvetlendirdiğini belirtirmiştir. Sosyal sermayenin temelinde iyi niyet ve birbirine yardım etme isteği vardır. Grup dayanışması, bireyin işini daha anlamlı kıldı̆̆ gibi işiyle özdeşlemesini de sağlamaktadır. Bu ise bireyin iş tatminini arttırmaktadır. Requena (2003)çalışmasında, sosyal sermayenin işyerinde hem yaşam kalitesinin hem de iş tatminin en önemli belirleyici olduğu sonucuna ulaşmıştır. Ayrıca sosyal aktörler arasında kolektif eylemi kolaylaştıran işbirlikçi ilişkiler düzeni olarak ele alınan sosyal sermaye, çalışanın, örgütün ve iş ortamının özelliklerinden çok daha güçlü bir iş tatmini belirleyicisi olduğu saptanmıştır.

Zaman içerisinde kalifiye eleman olma algısındaki değişim, bireylerin bu husustaki eğilimlerini de değiştirmiştir. İş piyasasında bireylerin beşeri sermayelerinin yanı sıra etkin ve verimli bir şekilde kurulan iletişim ağlarının güven esası ile sosyal sermaye dönüștürülebilmesi ve bunun doğru zaman ve yerde kullanabilmesi önem kazanmıştır. İşörenlerin bu bilince sahip olması ve bu doğrultuda sisteme yön vermesi tek taraflı bir güç değildir elbette ki. Söz konusu bilincin sağlanması ve yönetilmesinde yöneticilerin beklentileri, ekonomik koşullar, insan ihtiyaçları, teknoloji, küreselleşme gibi birçok faktör etkili olmaktadır. Özellikle bilgi teknolojisinin iș hayatında ivme kazanması örgüt ve yöneticileri bu yönde plan ve stratejiler yaratmaya itmiştir.

Beşeri ve sosyal sermaye açısından belirli bir düzeye erişmiş olan ve bu sermaye birikimlerini olumlu çıktılara dönüştürebilme kabiliyetine sahip olan işgörenin, iş yerine bağlılı̆̆ yöneticiler tarafından istenilen bir durumdur. Aynı șekilde söz konusu işgörenlerin de örgüt ve yöneticilerden yüksek ücret, mevkii, maddi olanaklar, terfi vb. gibi bir takım beklentilere sahiptir. $\mathrm{Bu}$ beklentilerin gerçekleşmesi veya gerçekleştirilebilecek fırsatların yaratılması işgörenin iş yerine bağlılığını arttııırken, aksi durum işgörenin işinde tatminsizlik yaşamasına ve nihai sonuç olarak işten ayrılma düşüncesi ile karşı karşıya gelmesine sebep olabilecektir. Bu durum, şu bakış açısı ile de irdelenebilir: Eğer işgören beșeri ve sosyal sermaye birikimini iş yeri sayesinde elde edebilmiş ve bundan istediği düzeyde getiri elde etmiş ise iş yerine minnet duygusu ile bağlanacaktır. Eğer işgören beşeri ve sosyal sermaye birikiminde iş yerinin herhangi bir katkısı yok ise, işgören beklentilerinin gerçekleşmemesi halinde kendini iş yerine bağlı hissetmeyecek ve daha iyi fırsatları değerlendirebilecektir.

\section{YÖNTEM}

\subsection{Araștırmanın Amacı ve Önemi}

Günümüzde, işgücü piyasasında işgörenlerin beşeri sermayelerinin (bilgi, beceri, tecrübe) yanında sosyal sermaye birikimlerinin de bireysel ve örgütsel açıdan artı değer yaratmaktadır. Çalışanların sahip oldukları sosyal çevre, bireylerin iş hayatındaki başarısını arttırdığı gibi iş yerinin de piyasa içerisindeki başarısını ciddi oranda etkilemektedir. Sosyal çevresi güçlü olan bireyler çalıştıkları yerlere maddi, manevi katkılar sağlarken yokluklarıyla söz konusu yerlerde bir takım kayıplara sebep olabilmektedir. Belirli bir sosyal sermaye düzeyine erişmiş ve bunu değere dönüştürebilme kabiliyetine sahip olan işgörenin işe ve iş yerine karşı memnuniyeti de 
oldukça önemlidir. $\mathrm{Bu}$ noktadan hareketle çalışmada, bireylerin sosyal sermaye ve iş tatmin algı düzeylerinin tespiti amaçlanmıştır.

\subsection{Araştırmanın Kapsamı ve Örneklem Seçimi}

Araştırmanın kapsamını, hedef kitle olarak GAP Bölgesi'nde faaliyet gösteren tüm bankalar oluşturmaktadır. Ancak araştırmanın başladığı tarihlerde ülke gündemindeki terör olayları, birçok il ve ilçede başlatılan sokağa çıkma yasakları ki söz konusu olayların çoğunlukla GAP Bölge İllerinde gerçekleşmiş olması araştırmayı sınırlandırmıştır. Bölgedeki güvenlik problemi ve kaos ortamı sebebiyle araștırma GAP Bölgesi'ni temsilen bölgenin en büyük üç ili olan Diyarbakır, Gaziantep ve Şanlıurfa ile sınırlandırılmıştır.

Araştırma kapsamındaki illerde, Gaziantep, Diyarbakır ve Şanlıurfa'da toplam 52 banka ve 346 şube bulunmaktadır. Gaziantep'te, toplam banka sayısı 23, toplam şube sayısı, 167, Diyarbakır'da, toplam banka sayısı, 15, toplam şube sayısı 97, Şanlıurfa'da toplam banka sayısı 14, toplam şube sayısı, 82 olarak belirlenerek tam sayıma gidilmiştir. Bu kapsamda örneklem, her bankayı bir işgören temsil edecek şekilde, görüşmelerin yapıldığı sırada kurumda bulunan en yetkili kişi şeklinde alınmıştır. Süreç sonunda toplamda 310 banka çalışanından veriler elde edilerek sonuçlar analiz edilmiştir. Kalan 36 bankanın araştırmaya dahil edilememesi, Diyarbakır'ın bazı illerindeki bir takım güvenlik sorunları ve bazı banka yöneticilerinin anketi doldurmayı reddetmesinden kaynaklanmaktadır.

\subsection{Verilerin Elde Edilmesi ve Analizi}

Araştırmada birincil veri toplama yöntemlerinden biri olan anket uygulaması kullanılmıştır. Araştırma verilerinin toplanmasında tesadüfi olmayan örneklem yöntemi kolayda örneklem tercih edilmiş ve araştırma yüz yüze uygulanmak suretiyle gerçekleștirilmiştir. Anket formunun birinci bölümünde demografik sorular yer alırken ikinci, üçüncü, dördüncü ve beşinci bölümlerinde 5’li Liket ölçeğine göre düzenlenmiş ifadeler yer almaktadır.

Anket formlarının değerlendirilmesinde ve sonuçların elde edilmesinde Tablo 1'den yararlanılmıştır. Söz konusu tabloya göre aritmetik ortalamalarının 1'e yakın olması değişkenlerin yüksek derecede algılandığını, 5'e yakın olması ise değişkenlerin düşük derecede algılandığını göstermektedir.

Tablo 1. Aritmetik Ortalamaların İsabet Ettiği Sonuç Değerlendirme Tablosu

\begin{tabular}{|c|c|}
\hline Değer (Aritmetik Ortalama) & Sonuç \\
\hline $00,1-1,00$ & Oldukça Yüksek Algı \\
\hline $1,01-1,99$ & Yüksek Algı \\
\hline $2,00-2,99$ & Orta Düzey Algı \\
\hline $3,00-3,99$ & Düşük Algı \\
\hline $4,00-5,00$ & Oldukça Düşük Algı \\
\hline
\end{tabular}

Verilerin analizinde kullanılan tanımlayıcı analizler kapsamında frekans ve yüzde analizi, aritmetik ortalama ve standart sapma değerlerinin elde edilmesinde SPSS 16.0 (Statistical Package for the Social Sciences) istatistik paket programindan yararlanılmıştır. Öte yandan verilerin normal dağılım gösterip göstermediğinin tespit 
edilmesi için Kolmogorov-Smirnov (K-S) testi yapılmış ve ölçeklerin geçerliliğini ve etkin gruplandırılmalarının sağlanabilmesi için Keşifsel Faktör Analizinden yararlanılmıştır.

Ölçeklerin güvenilirliğinin değerlendirilmesinde en yaygın metot olan Cronbach alfa testinden yararlanılmıştır. Değişkenlerin alfa değerleri aşağıdaki Tablo 2'de görülmektedir. Literatürde Cronbach alfa katsayısı 0,70 'den büyük olması sosyal bilimlerde içsel güvenilirlik için yeterli kabul edilmiştir.(Baum ve Wally,2003:1117) Tabloda da görüldüğü üzere araştırmada kullanılan ölçeklerin t alfa değerlerinin 0,70'den büyük olduğu tespit edilmiş olup, her iki ölçeğin güvenilirliğinin ise yüksek düzeyde olduğu ifade edilebilir.

Tablo 2. Ölçeklerin Güvenilirlik Değerleri

\begin{tabular}{|l|c|c|}
\hline \multicolumn{1}{|c|}{ Değişkenler } & $\begin{array}{c}\text { Soru } \\
\text { Sayısı }\end{array}$ & $\begin{array}{c}\text { Cronbach Alfa (a) } \\
\text { Değerleri }\end{array}$ \\
\hline İş Tatmini Ölçeği & 13 & 0,84 \\
\hline Sosyal Sermaye Algısı Ölçeği & 11 & 0,83 \\
\hline Tüm Değişkenler için Alfa Katsayısı & $\mathbf{2 4}$ & $\mathbf{0 , 8 4}$ \\
\hline
\end{tabular}

\subsection{Bulgular ve Değerlendirme}

Çalışmanın bu bölümünde araştırmaya ilişkin; güvenirlik analizi, keşifsel faktör analizi ile banka yöneticilerinin öncelikle demografik özellikleri hakkında bilgi verilmiş olup; sosyal sermaye ve iş tatminine ilişkin algı düzeylerinin belirlenmesi amacıyla frekans dağılımı, ortalama ve standart sapma değerlerine ilişkin bilgiler sunulmuş ve değerlendirmeler yapılarak analiz sonuçları yorumlanmıştır. 
Tablo 3. Katılımcıların Demografik Özellikleri

\begin{tabular}{|c|c|c|c|}
\hline Demografik Özellikler & & $\mathbf{F}$ & $\%$ \\
\hline \multirow[t]{2}{*}{ Cinsiyet } & Kadın & 160 & 51.6 \\
\hline & Erkek & 150 & 48.4 \\
\hline \multirow[t]{5}{*}{ Yaş } & $18-24$ & 9 & 2.9 \\
\hline & $25-34$ & 143 & 46.1 \\
\hline & $35-44$ & 106 & 43.2 \\
\hline & $45-54$ & 47 & 15.2 \\
\hline & 55 ve üzeri & 5 & 1.6 \\
\hline \multirow[t]{3}{*}{ Medeni Durum } & Evli & 232 & 74.8 \\
\hline & Bekar & 68 & 21.9 \\
\hline & Dul/Boșanmıș & 10 & 3.2 \\
\hline \multirow[t]{5}{*}{ Eğitim } & Lise & 5 & 1.6 \\
\hline & Ön Lisans & 24 & 7.7 \\
\hline & Lisans & 254 & 81.9 \\
\hline & Yüksek Lisans & 26 & 8.4 \\
\hline & Doktora & 1 & 0.3 \\
\hline \multirow[t]{2}{*}{ Yabancı Dil Biliyor musunuz? } & Evet & 195 & 62.9 \\
\hline & Hayır & 115 & 37.1 \\
\hline \multirow[t]{4}{*}{ Kaç Ylldır Bu İlde Çalışıyorsunuz? } & 1-5 Yll & 78 & 25.2 \\
\hline & 6-10 Yll & 55 & 17.7 \\
\hline & $11-15$ Yll & 15 & 4.8 \\
\hline & 16 Yll ve Üstü & 162 & 52.3 \\
\hline \multirow{4}{*}{$\begin{array}{l}\text { Şu anki İșyerinizde Kaç Yıldır } \\
\text { Çalışıyorsunuz }\end{array}$} & 1-5 Yll & 141 & 45.5 \\
\hline & 6-10 Yll & 105 & 33.9 \\
\hline & $11-15$ Yll & 22 & 7.1 \\
\hline & 16 Yll ve Üstü & 42 & 13.5 \\
\hline \multirow[t]{3}{*}{ İşinizden Memnun musunuz? } & Evet & 249 & 80.3 \\
\hline & Hayır & 19 & 6.1 \\
\hline & Kismen & 42 & 13.5 \\
\hline \multirow[t]{5}{*}{ İş Yerinizdeki Pozisyonunuz Nedir? } & Şube Müdürü & 89 & 28.7 \\
\hline & Müdür Yardımcısı & 70 & 22.6 \\
\hline & Uzman & 24 & 7.7 \\
\hline & Servis Yetkilisi & 75 & 24.2 \\
\hline & Diğer & 52 & 16.8 \\
\hline \multirow{2}{*}{$\begin{array}{l}\text { Pozisyon Olarak Olmak İstediğiniz } \\
\text { Yerde misiniz? }\end{array}$} & Evet & 222 & 71.6 \\
\hline & Hayır & 88 & 28.4 \\
\hline
\end{tabular}

Yukarıdaki Tablo 3.'deki demografik özellikler incelendiğinde; araştırmaya katılanların \%51.6'sı kadın ve \%48.4'ünün erkek olduğu görülmektedir. Örneklemin cinsiyet faktörüne göre dengeli bir dağılıma sahip olduğu görülmektedir. Araştırmaya katılanların grupları incelendiğinde, 18-24 yaş arası \%2,9, 25-34 yaş arası \%46,1, 35-44 yaş arası $\% 43,2,45-54$ yaş arası $\% 15,2$ ve 55 yaş üzeri ise $\% 1,6$ 'dır. Katılımcıların medeni durumları incelendiğinde ise, \%74,8'i evli, \%21,9'u bekâr ve \%3,2'si ve dul/boşanmış oldukları görülmektedir. Katılımcıların ğitim durumlarına bakıldığında, \% 1,6'sı lise, \% 
7,7'si ön lisans, \% 81,9'u lisan, \% 8,4'ü yüksek lisans ve \% 0,3'ü de doktora mezunu oldukları görülmektedir. Katılımcıların, \% 62,9'u yabancı dil bilirken, \%37,1'de yabancı dil bilmedikleri görülmektedir.

Katılımcıların \% 25,2'si 1-5 yıldır bulundukları șehirde yaşamaktadır, 6-10 yıl arası yaşayanlar \% 17,7'si oluşturmakta, 11-15 yıl arası yaşayanlar \% 4,8'sini oluşturmakta ve 16 yıl ve üzeri yaşayanlar ise \% 52,3'ünü oluşturmaktadır. Katılımcıların 1-5 yıl arası bu işyerinde çalışalar \% 45,5'ini oluşturmakta, 6-10 yıl arası çalışanlar \% 33,9'unu oluşturmakta, 11-15 yıl arası çalışanlar \% 7,1'ini oluşturmakta ve 16 yıl ve üzeri çalışanlar ise \% 13,5'ini oluşturmaktadır. Katılımcıların \% 80,3'ü işinden memnun oldukları ve \% 6,1'nin memnun olmadıkları ve \% 13,5'nin ise kısmen memnun oldukları görülmektedir. Katılımcıların \% 28,7'si şube müdürü, \% 22,6'sı müdür yardımcısı, \% 7,7'sinin uzman, \% 24,2'sinin servis yetkilisi ve \% 16,8'nin ise diğer personel olduğu görülmektedir. Katılımcıların \% 71,6'sının pozisyon olarak istedikleri yerde olduğu ve \% 28,4'nün de istedikleri pozisyonda çalışmadıkları görülmektedir.

Katılımcıların Kullanılan Ölçeklere Yönelik Algı Düzeyleri: Katılımcıların iş tatmini ve sosyal sermaye ilişkisine yönelik tutum ortalamaları ve standart sapmaları belirlenmiş ve sonuçlar aşağıdaki tablolarda gösterilmiştir.

Tablo 4. Katılımcıların İş Tatmini Ölçeğine Göre Yönelik Algıları

\begin{tabular}{|c|c|c|}
\hline Değişkenler & Ortalama & $\begin{array}{l}\text { Standart } \\
\text { Sapma }\end{array}$ \\
\hline $\begin{array}{l}\text { Çalışanların kişi, kurum ve düzenlemelere olan güveni iş } \\
\text { performansını etkilemektedir. }\end{array}$ & 1.70 & 0,845 \\
\hline Çalışanların iş memnuniyeti önemsenmektedir. & 1.93 & 0,888 \\
\hline Çalışanların iș yeri memnuniyeti önemsenmektedir. & 1.99 & 0,943 \\
\hline Çalışanların şikâyet ve itirazları dikkate alınmaktadır. & 1.92 & 1.01 \\
\hline Çalışanlar arası ilişkilerin kalitesine dikkat edilmektedir. & 1.85 & 0,885 \\
\hline $\begin{array}{l}\text { Çalışma ortam ve koşullarıyla ilgili } \\
\text { düzenlemelerde çalışan görüşlerine başvurulur. }\end{array}$ & 1.99 & 1.05 \\
\hline Çalıșanlar için adil ödüllendirme sistemi uygulanmaktadır. & 2.16 & 1.12 \\
\hline $\begin{array}{l}\text { Çalışanların motivasyonlarını arttırmak adına etkinlikler } \\
\text { düzenlenmektedir. }\end{array}$ & 1.99 & 0,950 \\
\hline $\begin{array}{l}\text { Çalışanların performansları belli periyodlarda incelenip } \\
\text { değerlendirmeye alınmaktadır. }\end{array}$ & 1.72 & 0,753 \\
\hline Çalıșanların performansları müșteri sayısını etkilemektedir & 1.61 & 0,611 \\
\hline $\begin{array}{l}\text { Müşterilerin çalışanlara olan güveni bankaya bağlılığını } \\
\text { arttırır. }\end{array}$ & 1.55 & 0,523 \\
\hline $\begin{array}{l}\text { Müşterilerin çalışanlara olan güveni bankanın verimliliğini } \\
\text { arttırır. }\end{array}$ & 1.56 & 0,534 \\
\hline $\begin{array}{l}\text { Müşterinin bankaya olan bağlılığı müşteri sayısından çok } \\
\text { daha önemlidir. }\end{array}$ & 1.75 & 0,826 \\
\hline
\end{tabular}

Katılımcıların iş tatmini ölçeğine ilişkin aritmetik ortalamalara bakıldığında çalışanların iş tatminine yönelik algı düzeylerinin genel olarak "yüksek" seviyede olduğu ( 
$\bar{x}: 1,81)$ söylenebilir. Bununla birlikte katılımcıların bankalarda en yüksek düzeyde algıladığı iş tatmin önermelerinin "Müşterilerin çalışanlara olan güveni bankaya bağlllığını arttırır önermesi" ( $\bar{x}$ :1.55) ile "Müşterilerin çalışanlara olan güveni bankanın verimliliğini arttırır" ( $\bar{x}: 1,56)$ önermesi olduğu tespit edilmiștir. Her iki önermeyi ise "Çalışanların performansları müşteri sayısını etkilemektedir" ( $\bar{x}: 1,61)$ önermesinin takip ettiği görülmektedir. Bununla birlikte bankalarda "çalışanlar için adil ödüllendirme sistemi uygulanmaktadır" $(\bar{x}: 2,16)$ önermesi ise katılımcılar tarafından en düşük düzeyde sahip olunan iș tatmini önermesi olduğu görülmektedir.

Tablo 5. Katılımcıların Sosyal Sermaye Ölçeğine İlişkin Algıları

\begin{tabular}{|l|c|c|}
\hline \multicolumn{1}{|c|}{ Değişkenler } & Ortalama & $\begin{array}{c}\text { Standart } \\
\text { Sapma }\end{array}$ \\
\hline $\begin{array}{l}\text { İşe alma sürecinde bireyin referansları dikkate } \\
\text { alınmaktadır. }\end{array}$ & 1.98 & 0,953 \\
\hline $\begin{array}{l}\text { İşe alırken tavsiye edilmiş olan bireylere öncelik } \\
\text { verilmektedir. }\end{array}$ & 2.18 & 1.02 \\
\hline $\begin{array}{l}\text { Çalışanların iş başvurusu yapan adaylarla ilgili fikirleri } \\
\text { dikkate alınmaktadır. }\end{array}$ & 2.17 & 1.05 \\
\hline $\begin{array}{l}\text { Mülakat sırasında bireyin sosyal açıdan özellikleri } \\
\text { irdelenmektedir. }\end{array}$ & 2.00 & 0,931 \\
\hline $\begin{array}{l}\text { İşe alma sürecinde bireyin sosyal çevre ile uyumuna ve } \\
\text { iletiş̧im gücüne önem verilmektedir. }\end{array}$ & 1.75 & 0,761 \\
\hline $\begin{array}{l}\text { Bankamızda sosyal sermaye düzeyi yüksek } \\
\text { çalışanlarımız bulunmaktadır. }\end{array}$ & 2.10 & 1.13 \\
\hline $\begin{array}{l}\text { Bankamız bünyesinde sosyal sermayesi güçlü çalışanlar } \\
\text { daha ayrıcalıklıdır. }\end{array}$ & 2.19 & 1.19 \\
\hline $\begin{array}{l}\text { Sosyal sermayesi güçlü çalışanların iş ve işyeri } \\
\text { memnuniyetleri önemsenmektedir. }\end{array}$ & 1.99 & 0,967 \\
\hline $\begin{array}{l}\text { Sosyal sermayesi güçlü çalışanların fikir ve kararları } \\
\text { bankamız tarafından desteklenmektedir. }\end{array}$ & 2.07 & 1.07 \\
\hline $\begin{array}{l}\text { Çalıssanların sosyal sermaye düzeylerini arttırmaya } \\
\text { yönelik etkinlikler düzenlenmektedir. }\end{array}$ & 2.10 & 1.10 \\
\hline $\begin{array}{l}\text { Sosyal sermaye düzeyi yüksek çalışanların varlığı, } \\
\text { bankaya rekabet üstünlüğü sağlamaktadır. }\end{array}$ & 1.94 & 0,990 \\
\hline
\end{tabular}

İlgili tablo incelendiğinde katılımcıların sosyal sermaye algı düzeylerinin genel olarak "yüksek" seviyede $(\bar{x}: 2,04)$ olduğu tespit edilmiştir. Öte yandan katılımcıların sosyal sermaye ölçeğinde en yüksek düzeyde algıladığı önermeler ise "İșe alma sürecinde bireyin sosyal çevre ile uyumuna ve iletişim gücüne önem verilmektedir" ( $\bar{x}: 1.75)$ önermesi ile "Sosyal sermaye düzeyi yüksek çalışanların varlığı, bankaya rekabet üstünlüğü sağlamaktadır" ( $\bar{x}$ :1.94) önermesi olduğu tespit edilmiştir. Her iki önermeyi ise "İșe alma sürecinde bireyin referansları dikkate alınmaktadır" ( $\bar{x}: 1.98)$ önermesinin takip ettiği görülmektedir. Katılımcıların sosyal sermaye ölçeğinde en düşük düzeyde algıladığı önerme ise "Bankamız bünyesinde sosyal sermayesi güçlü çalışanlar daha ayrıcalıklıdır" ( $\bar{x}: 2,19)$ önermesinin olduğu tespit edilmiştir. 
İs Tatminine İlişskin Faktör Analizi: İş tatmini ölçeğinin önermelerine iliş̧kin temel boyutları belirlemek için, toplam 13 adet önermeye, temel bileșenler yöntemi ile varimax rotasyonlu keşfedici faktör analizi uygulanmış ve 3 faktör elde edilmiștir. Elde edilen 3 faktör toplam varyansın \%60,11'ni açılamaktadır. Araştırma verilerine betimleyici faktör analizi uygulayabilme koşulunu gösteren KMO (Kaise-Meyer-Olkin Measure of Sampling Adequancy) örneklem yeterlilik ölçüsü $(0,814)$ ve araştırma verilerinden anlamlı sonuçlar çıkabileceğini gösteren küresellik derecesi (Barlett's Test of Aphericity; 1.625E3; $\mathrm{P}<, 000$ ) yeterli düzeyde olduğu tespit edilmiştir. Ayrıca tüm değişkenlerin güvenilirliğini gösteren Cronbach Alpha katsayısı 0,84'dür.

Tablo 6. İş Tatminine İlişkin Faktör Analizi Sonuçları

\begin{tabular}{|c|c|c|c|c|}
\hline Faktörler & $\begin{array}{l}\text { Faktör } \\
\text { Yükleri }\end{array}$ & $\begin{array}{c}\text { Öz } \\
\text { Değer }\end{array}$ & $\begin{array}{l}\text { Açlklanan } \\
\text { Varyans } \\
\%\end{array}$ & $\begin{array}{c}\text { Toplam } \\
\text { Varyans\% }\end{array}$ \\
\hline Faktör 1: Motivasyon ve Bağlılık & & 4.826 & 37.122 & 37.122 \\
\hline $\begin{array}{l}\text { 18.Çalışanların motivasyonlarını } \\
\text { arttırmak adına etkinlikler } \\
\text { düzenlenmektedir. }\end{array}$ & 0,808 & & & \\
\hline $\begin{array}{l}\text { 19.Çalışanların performansları belli } \\
\text { periyodlarda incelenip } \\
\text { değerlendirmeye alınmaktadır. }\end{array}$ & 0,755 & & & \\
\hline $\begin{array}{l}\text { 17.Çalışanlar için adil ödüllendirme } \\
\text { sistemi uygulanmaktadır. }\end{array}$ & 0,629 & & & \\
\hline $\begin{array}{l}\text { 16. Çalışma ortam ve koşullarıyla ilgili } \\
\text { yapılacak düzenlemelerde çalışan } \\
\text { görüșlerine başvurulur. }\end{array}$ & 0,567 & & & \\
\hline $\begin{array}{l}\text { 23.Müşterinin bankaya olan bağlılığı } \\
\text { müşteri sayısından çok daha } \\
\text { önemlidir. }\end{array}$ & 0,437 & & & \\
\hline $\begin{array}{c}\text { Faktör 2: Memnuniyet ve } \\
\text { Performans }\end{array}$ & & 1.912 & 14.705 & 51.827 \\
\hline $\begin{array}{l}\text { 13.Çalışanların iş yeri memnuniyeti } \\
\text { önemsenmektedir. }\end{array}$ & 0,753 & & & \\
\hline $\begin{array}{l}\text { 12.Çalışanların iş memnuniyeti } \\
\text { önemsenmektedir. }\end{array}$ & 0,719 & & & \\
\hline $\begin{array}{l}\text { 11.Çalışanların kişi, kurum ve } \\
\text { düzenlemelere olan güveni iş } \\
\text { performansını etkilemektedir. }\end{array}$ & 0,698 & & & \\
\hline $\begin{array}{l}\text { 14. Çalışanların şikâyet ve itirazları } \\
\text { dikkate alınmaktadır. }\end{array}$ & 0,655 & & & \\
\hline $\begin{array}{l}\text { 15.Çalışanlar arası ilişkilerin } \\
\text { kalitesine dikkat edilmektedir. }\end{array}$ & 0,597 & & & \\
\hline Faktör 3: Güven & & 1.077 & 8.283 & 60.11 \\
\hline $\begin{array}{l}\text { 22.Müşterilerin çalışanlara } \\
\text { güveni bankanın verimliliğini arttırır. } \\
\text {. }\end{array}$ & 0,855 & & & \\
\hline
\end{tabular}




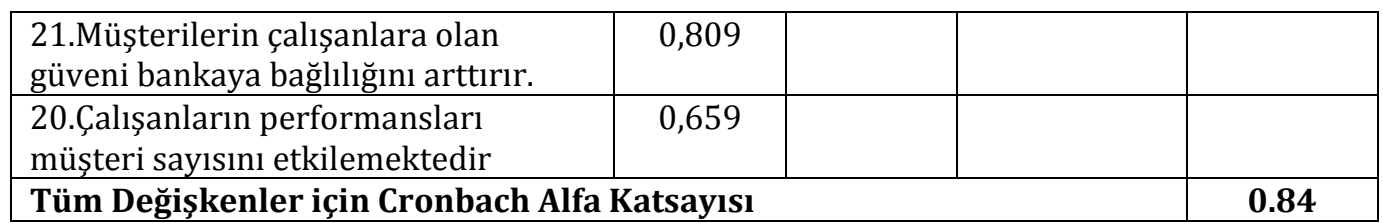

Analiz sonucunda elde edilen birinci faktörü niteleyen değişkenler motivasyon ve bağlılıkla ilgili değişkenlerdir. Buradan hareketle faktör 1 motivasyon ve bağlılık olarak adlandırılmıştır. Toplam 5 değişkenden oluşan motivasyon ve bağlılık faktörü, 4.826'lık bir öz değere sahip olup, toplam varyansın \% 37,122'sini açıklamaktadır. Memnuniyet ve Performans olarak adlandırılan ikinci faktörü niteleyen 5 değişken açıklanan varyansın \% 14.705'ni açıklamakta ve öz değeri 1,912'dir. Ölçeği oluşturan üçüncü faktör güven olarak adlandırılmış olup 3 değişkenden oluşmaktadır. Öz değeri 1.077 olup açıklanan varyansı 8.283'dür.

Sosyal Sermaye Algısına Ilişkin Faktör Analizi: Sosyal sermaye algısı değişkenlerine ilişkin temel boyutları belirlemek için, toplam 11 adet değişkene, temel bileşenler yöntemi ile varimax rotasyonlu faktör analizi uygulanmış ve 3 faktör elde edilmiştir. Elde edilen 3 faktör toplam varyansın \% 69.547'sini açıklamaktadır. Araştırma verilerine betimleyici faktör analizi uygulayabilme koşulunu gösteren KMO (Kaise-MeyerOlkin Measure of Sampling Adequancy) örneklem yeterlilik ölçüsü $(0,847)$ ve araştırma verilerinden anlamlı sonuçlar çıkabileceğini gösteren küresellik derecesi (Barlett's Test of Aphericity; 1.676E3; $\mathrm{P}<, 000$ ) yeterli düzeydedir. Ayrıca tüm değişkenlerin güvenilirliğini gösteren Cronbach Alpha katsayısı 0.83'dür.

Tablo 7. Sosyal Sermaye Algısına İlişkin Faktör Analizi Sonuçları

\begin{tabular}{|c|c|c|c|c|}
\hline Faktörler & $\begin{array}{l}\text { Faktör } \\
\text { Yükleri }\end{array}$ & $\begin{array}{c}\text { Öz } \\
\text { Değer }\end{array}$ & $\begin{array}{l}\text { Açılklanan } \\
\text { Varyans \% }\end{array}$ & $\begin{array}{c}\text { Toplam } \\
\text { Varyans \% }\end{array}$ \\
\hline $\begin{array}{c}\text { Faktör 1: Sosyal Sermayesi Güçlü } \\
\text { Çalışanlar }\end{array}$ & & 4.565 & 41.502 & 41.502 \\
\hline \begin{tabular}{lccr} 
32.Sosyal & \multicolumn{2}{c}{ sermayesi } & güçlü \\
çalışanların fikir ve & kararları \\
bankamız & & & tarafından \\
desteklenmektedir. & &
\end{tabular} & 0,906 & & & \\
\hline $\begin{array}{l}\text { 34.Sosyal sermaye düzeyi yüksek } \\
\text { çalışanların varlığı, bankaya rekabet } \\
\text { üstünlügü sağlamaktadır. }\end{array}$ & 0,864 & & & \\
\hline 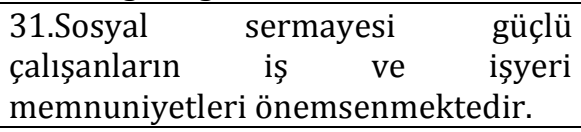 & 0,862 & & & \\
\hline \begin{tabular}{lrr} 
33.Çalışanların & \multicolumn{1}{c}{ sosyal } & sermaye \\
düzeylerini & arttırmaya & yönelik \\
etkinlikler düzenlenmektedir. & \\
\end{tabular} & 0,857 & & & \\
\hline $\begin{array}{l}\text { 30.Bankamız bünyesinde } \\
\text { sermayesi güçlü çalışanlar daha } \\
\text { ayrıcalıklıdır. }\end{array}$ & 0,777 & & & \\
\hline $\begin{array}{lrrr}29 . & \text { Bankamızda } & \text { sosyal } & \text { sermaye } \\
\text { düzeyi } & \text { yüksek } & \text { çalıșanlarımız }\end{array}$ & 0,713 & & & \\
\hline
\end{tabular}




\begin{tabular}{|l|l|l|l|l|}
\hline bulunmaktadır. & & & \\
\hline Faktör 2: Referans ve Tavsiye & & $\mathbf{2 . 0 4 6}$ & $\mathbf{1 8 . 6 0 3}$ & $\mathbf{6 0 . 1 0 5}$ \\
\hline $\begin{array}{l}\text { 25.İșe alırken tavsiye edilmiş olan } \\
\text { bireylere öncelik verilmektedir. }\end{array}$ & 0,847 & & & \\
\hline $\begin{array}{l}\text { 24.İșe alma sürecinde bireyin } \\
\text { referansları dikkate alınmaktadır. }\end{array}$ & 0,796 & & & \\
\hline $\begin{array}{l}\text { 26.Çalışanların iş başvurusu yapan } \\
\text { adaylarla ilgili fikirleri dikkate } \\
\text { alınmaktadır. }\end{array}$ & 0,610 & & $\mathbf{9 . 4 4 2}$ & $\mathbf{6 9 . 5 4 7}$ \\
\hline Faktör 3: Sosyal Özellikler & & $\mathbf{1 . 0 3 9}$ & \\
\hline $\begin{array}{l}\text { 28. İşe alma sürecinde bireyin sosyal } \\
\text { çevre ile uyumuna ve iletişim gücüne } \\
\text { önem verilmektedir. }\end{array}$ & 0,863 & & & \\
\hline $\begin{array}{l}\text { 27.Mülakat sırasında bireyin sosyal } \\
\text { açıdan özellikleri irdelenmektedir. }\end{array}$ & 0,769 & & & $\mathbf{0 . 8 3}$ \\
\hline Tüm Değişkenler için Cronbach Alfa Katsayısı & & & \\
\hline
\end{tabular}

Analiz sonucunda elde edilen birinci faktörü niteleyen değişkenler sosyal sermayesi güçlü çalışanlar ile ilgili değişkenlerdir. Buradan hareketle faktör 1 sosyal sermayesi güçlü çalışanlar olarak adlandırılmıştır. Toplam 6 değişkenden oluşan sermayesi güçlü çalışanlar faktörü, 4,565'lik bir öz değere sahip olup, toplam varyansın \% 41.502'sini açıklamaktadır. Referans ve tavsiye olarak adlandırılan ikinci faktörü niteleyen 3 değişken açıklanan varyansın \% 18.603'nü açıklamakta ve öz değeri 2.046'dır. Üçüncü faktör 3 sosyal özellikler olarak adlandırılmış olup 2 değişkenden oluşmaktadır. Sosyal özellikler boyutunun öz değeri 1.039 olup açıklanan varyansı 9.442'dir.

\section{SONUÇ}

Sosyal sermaye bireylerin güven, adalet, dürüstlük, fedakârlık, dayanışma, iyi niyet gibi sosyal erdemlerin bulunduğu toplumun çıkarları doğrultusunda değere dönüştürebilmeye teşvik eden bir güçtür. Bu gücü faaliyete geçiren en önemli faktör ise bireylerin birbirlerine, topluma, idari ve siyasi otoriteye ve normlara olan güvendir. Güvene dayalı karşılıklı ilişkilerin ekonomik yansıması olarak da ifade edilen sosyal sermaye, taraflar arasındaki bu döngüsel hareket ile toplumda huzuru sağlarken bireylerin gelecek kaygısını azaltacaktır. İşgörenlerin birtakım eylemleri gerçekleştirmek, kolaylaştırmak, devamlılığını sağlamak veya belirlediği amaçlara ulaşabilmelerinde sosyal sermaye birikimleri etkili olmaktadır. Belirli bir sosyal sermaye düzeyine sahip olan bir işgören, sahip olduğu sosyal ilişkiler sayesinde bilgiye ulaşımı kolaylaşacak ve muhtemel firsat ve imkânları yakalama konusunda avantaj sağlayacaktır. Bu noktadan hareketle bireysel getiri sağlayan işgören örgütsel verimlilik ve performans üzerinde de etkili olacaktır. Örgütsel verimlilik ve performansın nihai sonucu olarak görülen iş tatmini, günümüzde örgütlerin mevcut ve gelecek durumunu ifade eden göstergelerden biri olarak kabul edilirken, işgörenlerin örgüte bağlılık ve sadakatini arttırmaktadır.

Sosyal ve beșeri sermaye düzeyi yüksek olan işgörenin işinden ve işyerinden beklentisi de yüksek olacaktır. Maddi ve manevi açıdan tatmin olan işgören, etik kurallar dışına çıkmayacak ve böylece örgütün menfaatlerini olumsuz etkileyecek davranışlarda bulunmayacaktır. Diğer bir deyişle söz konusu işgören kendi kişisel çıkarları için örgütün menfaatlerini riske atmayacaktır. $\mathrm{Bu}$ noktadan hareketle, çalışmada temelini güvene 
dayalı karşılıklı ilişsilerin oluşturduğu bankalarda faaliyet gösteren işgörenlerin, sosyal sermaye düzeylerinin iş tatminlerini ne derece etkilediğinin tespiti amaçlanmıştır.

Araştırma kapsamında önce örneklem grubunu oluşturan banka çalışanlarının konu ile ilgili genel profilininden bahsetmek sonuçların değerlendirilmesinde fayda sağlayacaktır. \%51,6'sının kadın ve \%48,4'ü erkeklerin oluşturduğu katılımcıların \% 81,9'u lisans mezunudur. Katılımcıların bulunduğu bankada çalışma süresi incelendiğinde \% 45,5'inin 1- 5 yıl arasında, \% 33,9'u ise 6-10 yıl olduğu görülmüștür. Ayrıca "Şu anki işinizden memnun musunuz?" sorusuna katılımcıların \% 80,3'ü "Evet" cevabını verirken \% 6,1'inin "Hayır" cevabını verdiği, \% 13,5'inin ise çalıștıkları işlerinden kısmen memnun olduklarını tespit edilmiştir. Öte yandan katılımcıların \% 71,6'sı şuanda bulunduğu pozisyonun istediği yer olduğunu belirtirken \% 28,4'ü ise şuanda bulunduğu pozisyonun istediği yer olmadığını belirttiği söz konusu araştırmada ortaya konulan diğer bir bulgu olmuştur. Söz konusu sonuçlar değerlendirildiğinde katılımcıların büyük bir kısmının mevcut işinden memnun olduğunu ve yine yaklaşık oranda katılımcıların işyerindeki pozisyonlarının istedikleri yer olduğunu söylemek mümkündür.

Katılımcıların iş tatmini ölçeğine ilişkin aritmetik ortalama sonuçları işgörenlerin iş tatminine yönelik algı düzeylerinin genel olarak "yüksek" seviyede olduğu $(: 1,81)$ göstermektedir. Bununla birlikte katılımcıların bankalarda en yüksek düzeyde algıladığı iş tatmin önermelerinin çoğunun güven ile ilgili oluşu dikkat çekmektedir. Bankacılık sektörünün güvene temelinde şekillenen insan ilişkileri ile faaliyet gösterdiği düşünüldüğünde, bu sonucun yerinde olduğunu söylemek mümkündür. Öte yandan müşterilerin bankaya ve çalışanlara karşı güven duymasının bireysel ve örgütsel performansı arttırırken müşterilerin bankaya olan bağlılı̆̆ını arttırdığı sonucuna varılmıştır. Diğer taraftan bankalarda "çalışanlar için adil ödüllendirme sistemi uygulanmaktadır" $(: 2,16)$ önermesi ise katılımcllar tarafından en düşük düzeyde sahip olunan iş tatmini önermesi olduğu görülmektedir. Katılımcıların büyük çoğunluğunun işinden memnun olmasına rağmen bankanın işgörenler arasında adil ödüllendirme sistemi uygulamadığını düşünmelerinde sosyal sermayenin etkili olduğu düşünülmektedir. Şöyle ki sosyal çevresini değere dönüştürebilen işgören sosyal sermaye birikimini arttıracak ve belirli bir müșteri portföyüne sahip olacaktır. Bu sayede müşteri sayısındaki artış ve istikrar örgütsel getiriyi de beraberinde getirecektir. Dolayısıyla müşteriler tarafından tercih edilen işgören örgüte sağladığı getiri neticesinde maddi ve manevi açıdan ödüllendirilecektir.

Sosyal sermayenin ekonomik ve sosyal birçok olumlu etkisi söz konusudur. Güçlü sosyal sermaye, ekonomik büyümeye, işgücü piyasalarının etkin çalışmasına, toplumun eğitim ve sağlık düzeyine, suç oranının azalmasına, kamu kurumlarının etkin çalışmasına katkıda bulunur. Özellikle işgücü piyasasının etkinliği bireylerin eș, dost, tanıdık, arkadaș çevresi ile olan kişisel ilişkilere bağlıdır. İşsiz bir bireyin sosyal çevresinin genişliği, tanıdığı kişi sayısı veya tanınma düzeyi ölçüsünde iş bulma süreci kısalır ve daha az maliyetli olur. Böylelikle işsizlik süresi kısalırken işgücü piyasalarının etkinliği artar. Katılımcılarımızın sosyal sermaye algı düzeyleri incelendiğinde "yüksek" seviyede ( $\bar{x}$ $: 2,04$ ) olduğu tespit edilmiştir. Öte yandan sosyal sermaye ölçeğinde yüksek düzeyde algılanan önermelere bakıldığında bankaların ișe alma sürecinde bireyin sosyal çevre ile uyumuna ve iletişim gücüne öncelik verdikleri ve sosyal sermaye düzeyi yüksek işgörenlerin, kurum için rekabet üstünlüğü sağladığına inandıkları tespit edilmiştir. 
Ayrıca işe alma sürecinde bireylerin referanslarının süreci hızlandırmada etkili olduğu dikkat çekmektedir

İşgören sahip olduğu sosyal sermaye birikimi ile işgücü piyasasındaki fırsat ve olanaklara kolayca erişebilme imkânı elde edebilecek ve kendisi ile başka bir işgören arasında karşılaştırma yapabilecektir. İşgörenin, beşeri sermayesinin yanında değere dönüştürülebilen sosyal ilişkilere de sahip olması kişiyi mevcut koşul ve taraflara karşı daha güçlü ve gerektiğinde müdahale edebilecek bir birey olmasını sağlayacaktır. Çalıștığı iş yerinden maddi ve manevi açıdan doyuma ulaşamayan ve belli bir sosyal sermaye birikimine sahip olan işgörenin örgüte bağlılığı azalacak ve ilk firsatta mevcut durumu iyileştirmek için girişimde bulunacaktır. Özellikle güvene dayalı ilişskiler temelinde faaliyet gösteren bankacılık sektöründe, söz konusu bu durumuna sıkça rastlanmaktadır. Şöyle ki, karşılıklı güvene dayalı ilişkiler neticesinde belirli bir müşteri portföyüne sahip olan banka çalışanı yaşadığı iş tatminsizliği neticesinde mevcut işinden ayrılarak bir başka bankaya geçerken söz konusu müşterilerin bir kısmının da geçiş yapmasına neden olabilecektir. Bu durum işgörenin çalıștığı banka için bir takım kayıplara sebep olurken geçiş yapacağı banka için getiri sağlayacaktır. Söz konusu bu durumun sektörde ranta dönüşmesi, etik kuralları zedelerken işgörenler arasındaki adaleti etkileyebilecektir. 


\section{KAYNAKÇA}

Eren E.(2006). Örgütsel Davranış ve Yönetim Psikolojisi, Beta Yayıncılık, İstanbul.

Erselcan F. (2009). Disiplinlerarası Ortak Bir Çalışma Alanı Olarak Sosyal Sermaye C.Ü. Sosyal Bilimler Dergisi, Aralık 2009, Cilt: 35, Sayı: 2, s.s.248-256.

Field J. (2008). Sosyal Sermaye, İstanbul Bilgi Üniversitesi Yayınları, Çev. Bahar Bilgen ve Bayram Şen.

Hodson 0. R. (1997). "Group Relations at Wor", Work and Occupations, Cilt. 24, No.4, 1997, ss. 426-452.

Karagül M. (2012). Sosyal Sermaye (Kapitalizmin Kör Noktası), Nobel Yayınları.

Karagül M. ve Dündar S. (2006). Sosyal Sermaye Ve Belirleyicileri Üzerine Ampirik Bir Çalışma, Akdeniz LLB.F. Dergisi (12),ss. 61-78.

Montgomery, J.D. (1991), "Social networks and labor-market outcomes: Toward an economic analysis", American Economic Review, 81, pp. 1408-1418.

Öğ̈̈t Â. ve Erbil C. (2009). Sosyal Sermaye Yönetimi: Strateji Enformasyon, Güven. Çizgi Kitapevi.

Putnam R. (1993). Making Social Capital Work: A Review of Robert Putnam's Making Democracy Work: Civic Traditions in Modern Italy, Princeton Universty Pess.

Requena F. (2003). "Social Capital, Satisfaction and Quality of Life in the Workplace", Social Indicators Research, Cilt. 61, No. 3, 2003, ss. 331-360.

Robert Baum J. ve Wally S. (2003). Strategic Decision Speed And Firm .

Seibert, S.E., Kraimer, M.L. And Liden, R.C. (2001), “A Social Capital Theory of Career Success", Academy of Management Journal, Vol:44 No:2, pp. 219-225.

Woolcok M. (1998), "Social Capital and Economic Development: Toward a Theoretical Synthesis and Policy Framework, Theory and Society, 27, ss. 151-208.

World Bank. (1998). The Initiative on Defining, Mentoring and Measuring Social Capital: Over view And Program Description", Social Capital Initiative Working Paper No: 1, pp.1-33. 